\title{
THERMODYNAMIC ANALYSIS OF ELECTRIC POWER PRODUCTION TECHNOLOGIES IN COGENERATION SYSTEMS ON FPSO AIMING TO REDUCE $\mathrm{CO}_{2}$ EMISSIONS
}

\author{
A. G. Gallego, \\ A. C. C. Souza, \\ P. H. Morais, \\ and M. Modesto \\ Universidade Federal do ABC \\ Centro de Engenharia, Modelagem e Ciências \\ Sociais Aplicadas \\ Bairro Bangu \\ CP. 09210-580, Santo André, São Paulo, Brasil \\ a.gallego@ufabc.edu.br \\ augusto.cesar@aluno.ufabc.edu.br \\ pedro.morais@aluno.ufabc.edu.br \\ marcelo.modesto@ufabc.edu.br \\ Received: Jan 18, 2021 \\ Revised: Mar 26, 2021 \\ Accepted: Mar 30, 2021 \\ ABSTRACT \\ configuration

\section{NOMENCLATURE} \\ m Mass flow, $\mathrm{kg} / \mathrm{s}$ \\ $\mathrm{c}_{\mathrm{p}}$ fluid specific heat at constant pressure, \\ $\mathrm{J} /(\mathrm{kg} . \mathrm{K})$ \\ $\dot{\mathrm{Q}}$ Overall heat transfer rate, $\mathrm{kW}$ \\ $\mathrm{h}$ Enthalpy, $\mathrm{kJ} / \mathrm{kg}$ \\ $\mathrm{N}$ Nitrogen \\ C Carbon \\ $\mathrm{H}$ Hydrogen \\ O Oxygen \\ Lo Load, \% \\ W Power, $\mathrm{kW}$ \\ $\mathrm{T} \quad$ Temperature, ${ }^{\circ} \mathrm{C}$ \\ $\mathrm{x} \quad$ Mass fraction \\ y Molar fraction \\ M Molar mass, $\mathrm{kmol} / \mathrm{kg}$
}

\section{Greek symbols}

$\eta \quad$ Efficiency, \%
Oil platforms are complex structures used to host workers and equipment needed in offshore exploration. This study focuses on the platform's heat and electricity cogeneration plant, which supplies a process heat exchangers net, and provides the necessary electricity for all the equipment used for the process and worker's accommodation in the platform. The platform demand with maximum load is $75 \mathrm{MW}$, which could be achieved using four gas turbines (25 MW each), one of which is kept for backup purposes or using six dual-fuel engines diesel/natural gas (15 MW each), one of which is also kept for backup purposes. Therefore, the thermodynamic analysis was performed - considering five specific demand points of the platform comparing the two traditional configurations (gas turbines and dual-fuel engines diesel/natural gas) and a combined configuration. The combined configuration is composed of three gas turbines and two dual-fuel engines diesel/natural gas (one of the gas turbines kept for backup purposes). The configurations presented respectively $35.5 \%, 48.4 \%$ and $42.6 \%$ at highest overall efficiency; $611.34 \mathrm{~g} / \mathrm{kWh}, 373.45 \mathrm{~g} / \mathrm{kWh}, 472.74 \mathrm{~g} / \mathrm{kWh}$ at lowest $\mathrm{CO}_{2}$ emissions considering full attendance of electrical and thermal demands. The configurations using only gas turbines and the combined fully attended the thermal demand of the platform without using auxiliary pieces of equipment. Therefore, it was possible to observe that the combined configuration presented several advantages concerning isolated systems, proving to be an excellent option for sustainable energy generation, reducing emissions of polluting gases and greater flexibility of its operation concerning to configuration only with turbines, and physical occupation in relation to configuration only with engines.

Keywords: cogeneration, gas turbine, diesel/natural gas engine, combined

\section{INTRODUCTION}

Offshore exploration began in the late 19th century, in ultra-shallow waters (depths up to 30 meters), where the same technological standard as onshore exploration was used with some improvements. With the expansion of discoveries to shallow waters (between 30 and 400 meters), there was a need to develop procedures and technologies specific to this environment. With the many advances, it was possible to reach ultra-deep fields (more than 1500 meters) in the 1990s (Neto and Shima, 2008). Thus, FPSO (Floating, Production, Storage, and Offloading) unit development took place due to their low construction cost, this occur due many groups were transporting restructured oil tankers for such a vast deck area that allows the installation of equipment for the production and generation of energy (which grants it selfsufficiency). In addition to high storage capacity, it was eliminating the necessity of pipelines construction for transportation to the coast (Leffler et al., 2003). 
With the availability of a technological solution for offshore exploration, there was a significant increase in the total volume of oil and gas available to prospects. As a result, approximately $30 \%$ of the world's oil and gas production came from offshore exploration (Neto and Shima, 2008).

In Brazil, the use of FPSO units has enabled the exploration of oil in areas of ultra-deep waters such as pre-salt, which makes the pipeline construction for the transportation of oil impracticable. The Brazilian pre-salt fits precisely in this context, which is why Brazil is among the most significant users of FPSO units in the world. In a research conducted by Wood Group Mustang, released by the National Union of the Naval Construction and Repair Industry Offshore (SINAVAL), Brazil was appointed as the world's largest user of FPSO units, operating 37 units out of 161 in operation worldwide (Silva, 2016).

The FPSO needs heat and electricity to attend to the production and processing of hydrocarbons, and oil storage. Therefore, a cogeneration plant composed of heat recovery and gas turbine, or dual fuel engine diesel/natural gas, is usually present in FPSO units (Silva, 2016). This type of system is responsible for producing the thermal energy required for the process and the necessary electricity for all the equipment used for the process and worker's accommodation in the platform. This system is also responsible for most of the $\mathrm{CO}_{2}$ emissions in the FPSO, almost $60 \%$ of the total (Acevedo, 2016); therefore, it is essential to find the system that supplies the energy required, with the lowest $\mathrm{CO}_{2}$ emission, throughout the operating life of the platform.

For this reason, three cogeneration plants were compared: gas turbines and heat recovery (Scenario 1); dual-fuel engines diesel/natural gas and heat recovery (Scenario 2); finally, the configuration proposed using gas turbines and dual-fuel engines diesel/natural gas, besides heat recovery (Scenario 3). Thus, the objective was to make a comparative thermodynamic analysis of each proposed taking in count the efficiency, $\mathrm{CO}_{2}$ emissions, weight, and space occupied by the analyzed systems.

\section{DESCRIPTION OF THE PROCESS}

The production curves in oil fields show a characteristic behavior, and the production gradually grows at the beginning of the exploration until reaching a peak of production, from which the production decays until the exploration becomes economically infeasible, at that moment, the platform deactivation process begins (Dias, 2017).

The oil field chosen for the analysis was field 2 of the Brazilian pre-salt, called "Carioca", the object of study of the works of Dias (2017) and Viana (2017). The main reason for choosing this field was comparing the data obtained using the gas turbine configuration (Dias, 2017) and the data presented using dual-fuel engines diesel/natural gas proposal (Viana, 2017). Besides, this is the pre-salt oil field with the highest electrical demand under normal operating conditions (Dias, 2017) with a $75 \mathrm{MW}$ maximum load project condition for the platform (Viana, 2017). In Fig. 1, Viana (2017) showed the accumulated production curve for this field and the highlighted points to be the object of study/simulations. There are five decisive points (marked by vertical lines) corresponding to the moments: Point 1, "Max. O\&G" (Maximum Oil and Gas); Point 2, "Intermediate"; Point 3, "Valley"; Point 4, "50\% BSW" (Basic Sediment and Water); and Point 5, "Max. $\mathrm{H}_{2} \mathrm{O} / \mathrm{CO}_{2}$ "; these points correspond respectively to the years 2018, 2028, 2031, 2034, and 2037.

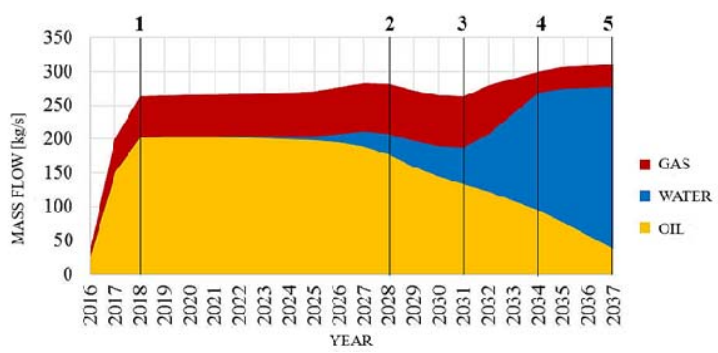

Figure 1. Expected cumulative production curve of the "Carioca" oil field (Viana, 2017)

Figure 1 shows that production increases very quickly in the first two production years of the platform and remains relatively constant for the next seven years, from when a considerable increase in water production is noted, and as a result, decreased oil production (Viana, 2017). The characteristic of the production of these types of processes is explained by Gallo et al. (2017) and Dias (2017). From this, it highlights the points:

Point 1, "Max. O\&G" where the platform produces and treats oil and gas near its maximum capacity. The high amount of gas moved by the treatment process involves high energy consumption in the main compression, exportation, and injection units.

Point 2, "Intermediate," featured by the moment when water production starts impacting the platform's operation parameters.

Point 3, "Valley," is characterized by a slight decrease in all fluids production (Gas, Oil, and Water).

Point 4, " $50 \%$ BSW," the main feature is the partial load operation of the equipment related to the gas treatment, particularly compressors and heat exchangers, as well as handling of large quantities of produced water.

Point 5, "Max. $\mathrm{H}_{2} \mathrm{O} / \mathrm{CO}_{2}$ " refers to the final stages of oil and gas production on the platform, with high production of $\mathrm{CO}_{2}$ in the associated gas as a 
result of prior $\mathrm{CO}_{2}$ injection into the reservoir as an enhanced recovery technique. Similarly, high quantities of water are produced due to earlier-stage injection.

This change in the fluid produced, mainly at the two final characteristic points, changes the electric demand and heat demand behavior of the platform, as shown in Tab. 1. It's possible to highlight that the electric demand of the process is showing (column 2) for each operating point FPSO (column 1). The ratio between the electric demand of the process and the maximum amount of power generation (3), and the thermal demand of the process in each operating point (4). The cogeneration system provides the thermal process with hot water (5) at a $130^{\circ} \mathrm{C}$. The hot water returns the process with the temperature, as shown in column 6.

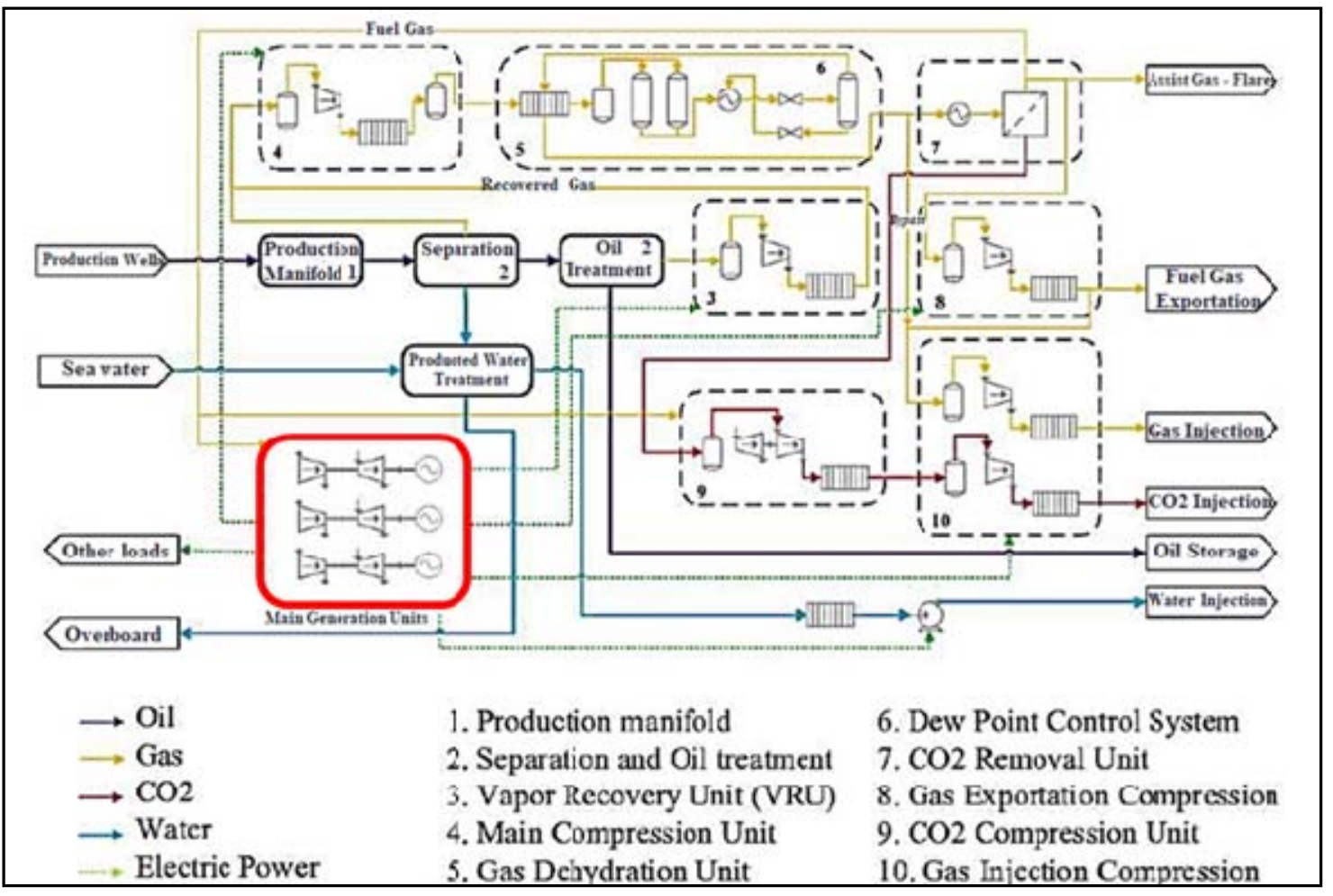

Figure 2. Simplified flowsheet of FPSO processes (Gallo et al., 2017).

Table 1. Demand points characteristics. Adapted from Viana (2017).

\begin{tabular}{|c|c|c|c|c|c|}
\hline $\begin{array}{c}\text { Operating } \\
\text { Points } \\
\text { FPSO (1) }\end{array}$ & $\begin{array}{c}\text { Electric } \\
\text { Demand } \\
{[\mathbf{k W}] \text { (2) }}\end{array}$ & $\begin{array}{c}\text { Platform } \\
\text { Load } \\
{[\mathbf{M a x} 75} \\
\mathbf{M W} \text { (3) }\end{array}$ & $\begin{array}{c}\text { Thermal } \\
\text { Demand } \\
{[\mathbf{k W} \text { (4) }}\end{array}$ & $\begin{array}{c}\text { Process } \\
\text { Water } \\
\text { Demand } \\
{[\mathbf{k g} / \mathbf{s}]} \\
\mathbf{( 5 )}\end{array}$ & $\begin{array}{c}\text { Water } \\
\text { Return } \\
\text { Temp. } \\
{\left[{ }^{\circ} \mathbf{C}\right] \mathbf{( 6 )}}\end{array}$ \\
\hline Max O\&G & 63,748 & $85.00 \%$ & 44,305 & 431.1 & 105.8 \\
\hline Intermediate & 65,008 & $86.68 \%$ & 43,044 & 413.7 & 105.5 \\
\hline Valley & 62,973 & $83.96 \%$ & 40,930 & 390.2 & 105.3 \\
\hline $50 \% \mathrm{BSW}$ & 42,890 & $57.19 \%$ & 46,183 & 307.2 & 94.6 \\
\hline $\begin{array}{c}\mathrm{Max} \\
\mathrm{H}_{2} \mathrm{O} / \mathrm{CO}_{2}\end{array}$ & 40,700 & $54.27 \%$ & 39,825 & 268.7 & 95.1 \\
\hline
\end{tabular}

The thermal demand of each demand point was calculated using the Eq. (1), considering the water outlet temperature required of $130^{\circ} \mathrm{C}$ (Viana, 2017) for the process.

$$
\dot{\mathrm{Q}}=\dot{\mathrm{m}} \Delta \mathrm{h}
$$

Where: represents the water's enthalpy variation, a function of the temperatures presented in Tab.1, and the outlet temperature of $130{ }^{\circ} \mathrm{C}$, as mentioned above. Figure 2 illustrates the main processes carried out in an oil field that has the electrical and thermal demands supplied by the main generation units.

The main generation units in Fig. 2 are represented by gas turbines, and this is due to the current scenario in FPSO being characterized by the use of gas turbines, where each has its exhaust system coupled to a heat exchanger, as shown in Fig. 3, to raise the temperature of the process water.

The typical cogeneration system in the FPSO platform uses the gas turbine due to the high-power density $(\mathrm{kW} / \mathrm{m} 3)$ and specific power $(\mathrm{kW} / \mathrm{kg})$ compared to the internal combustion engine. The low 
physical occupancy (weight and volume) is an important design parameter for an FPSO.

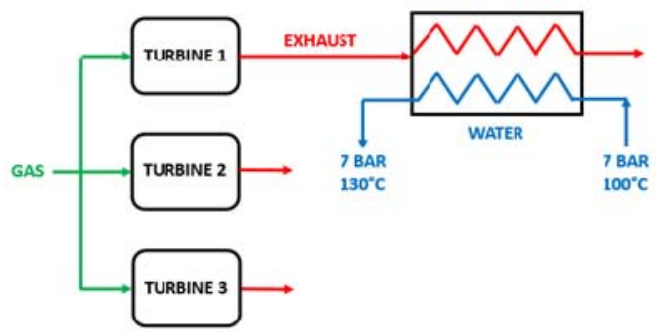

Figure 3. Schematic design of Scenario 1. Adapted from Viana (2017).

These characteristics are essential for platforms of this type since they are isolated, floating systems with limited space (Viana, 2017). However, gas turbines have low energy efficiency when operating at partial load than internal combustion engines (Viana, 2017). This is the main cause of the engines being gradually introduced in this market since they have substantially higher efficiency values than gas turbines (Dias, 2017). The configuration using dual-fuel engines plus the thermal exchange system is presented in Fig. 4.

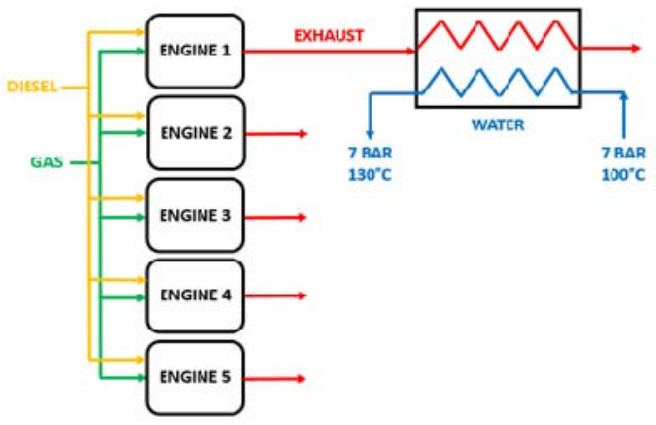

Figure 4. Schematic design of scenario 2. Adapted from Viana (2017).

The fuel used in both gas turbines and dualfuel engines comes from the natural gas produced by the platform, according to the molar composition set out in Tab. 2. However, in the scenario using engines, an additional fuel current line (diesel) is perceived, and this occurs because the dual-fuel engine utilizes a lean-burn combustion process. The gas is mixed with air before the intake valves during the air intake period. After the compression phase, the gas-air mixture is ignited by a small amount of liquid pilot fuel (Wärtsilä, 2020). Wärtsilä guarantees that its engines run with a fraction of up to $95 \%$ gas (Viana, 2017), and the remaining 5\% fraction is characterized by diesel consumption in the pilot injection. The molar composition adopted to represent the diesel fraction was C14,5H25 (Viana, 2017).
Table 2. The molar composition of fuel produced by the platform (Dias, 2017).

\begin{tabular}{|l|c|}
\hline Substance & Molar Fraction [\%] \\
\hline $\mathrm{N}_{2}$ & 0.560 \\
\hline $\mathrm{CO}_{2}$ & 2.998 \\
\hline $\mathrm{CH}_{4}$ & 7.664 \\
\hline $\mathrm{C}_{2} \mathrm{H}_{6}$ & 10.969 \\
\hline $\mathrm{C}_{3} \mathrm{H}_{8}$ & 6.653 \\
\hline $\mathrm{C}_{4} \mathrm{H}_{10}$, iso & 0.923 \\
\hline $\mathrm{C}_{4} \mathrm{H}_{10}, n$ & 1.549 \\
\hline $\mathrm{C}_{5} \mathrm{H}_{12}$, iso & 0.269 \\
\hline $\mathrm{C}_{5} \mathrm{H}_{12}, \mathrm{n}$ & 0.308 \\
\hline $\mathrm{C}_{6+}$ & 0.107 \\
\hline
\end{tabular}

However, the engines have lower mass exhaust gas flow than the turbines, which makes it difficult to attend to the platform's thermal demand, thus requiring auxiliary equipment. This option increases the platform's physical occupancy in comparison with the configuration using only gas turbines, especially concerning the weight of the engines (Dias, 2017). In order to reconcile the advantages of power density and the high available energy of turbine exhaust gases with the best efficiency of engines mainly in partial load, a new configuration was proposed, as shown in Fig. 5.

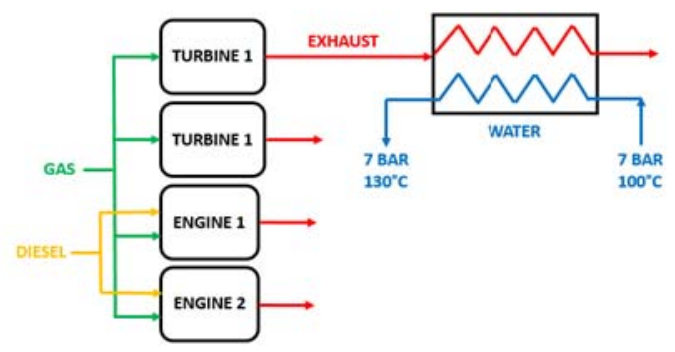

Figure 5. Schematic design of Scenario 3.

\section{METHODOLOGY}

In order to model the first configuration (Scenario 1), the data provided by Dias (2017) were used, as shown in Tab. 3. The values of the fuel molar composition of Tab. 2 were also used to calculate the Lower Heat Value (LHV) of the fuel with the lower heat value function of the software Engineering Equation Solver (EES).

Table 3. Rolls Royce RB211 gas turbine data. Adapted from Dias (2017).

\begin{tabular}{|c|c|c|c|c|}
\hline Load & $\begin{array}{c}\text { Power } \\
(\mathbf{k W})\end{array}$ & $\begin{array}{c}\text { Air mass } \\
\text { flow } \\
(\mathbf{k g} / \mathbf{s})\end{array}$ & $\begin{array}{c}\text { Fuel mass } \\
\text { flow } \\
(\mathbf{k g} / \mathbf{s})\end{array}$ & $\begin{array}{c}\text { Exhaust gas } \\
\text { temperature } \\
\left({ }^{\mathbf{}} \mathbf{C}\right)\end{array}$ \\
\hline $100 \%$ & $25,608.1$ & 83.78 & 1.551 & 501.92 \\
\hline $90 \%$ & $23,091.3$ & 80.57 & 1.418 & 483.80 \\
\hline $80 \%$ & $20,610.1$ & 77.72 & 1.295 & 466.65 \\
\hline $70 \%$ & $18,105.9$ & 74.67 & 1.170 & 448.58 \\
\hline $60 \%$ & $15,653.2$ & 71.46 & 1.047 & 429.50 \\
\hline $50 \%$ & $13,162.1$ & 67.90 & 0.920 & 408.50 \\
\hline
\end{tabular}


With the LHV calculated $(45351 \mathrm{~kJ} / \mathrm{kg})$, the mass flow values of fuel, and power supplied, it was possible to calculate the heat rate $(\mathrm{kJ} / \mathrm{kWh})$ and, consequently, the efficiency of a turbine for each operation load. With the values are shown in Tab. 3, was developed a procedure using the least-squares method, with the objective to find the parametric equations of efficiency, power, gas mass flow, and exhaust temperature, was developed according to the operating load. All the equations used in this work can be applied within the range of 50 to $100 \%$ of the load. Equation (2) shows the turbine efficiency from the operation load, represented by the variable Lo.

$$
\eta_{\text {turbine }}=-0.0011 \mathrm{Lo}^{2}+0.2584 \mathrm{Lo}+21.311
$$

The turbine's power was also parameterized according to Eq. (3).

$$
\mathrm{W}_{\text {turbine }}=-0.0433 \mathrm{Lo}^{2}+242.21 \mathrm{Lo}+949.49
$$

Thus, to evaluate the available heat at the exhaust gases to attend the thermal demand at the specific points, the flow and exhaust temperature values of a turbine were parameterized using Eq. (4) e Eq. (5), respectively.

$$
\begin{aligned}
& \mathrm{m}_{\text {exhaust,turbine }}=-0.0006 \mathrm{Lo}^{2}+0.4098 \mathrm{Lo}+49.81 \\
& \mathrm{~T}_{\text {exhaust,turbine }}=-0.004 \mathrm{Lo}^{2}+2.4441 \mathrm{Lo}+296.55
\end{aligned}
$$

These equations were used to calculate the thermal energy available in the exhaust gases of a turbine, according to Eq. (1), where the temperature considered at the heat exchanger exit was $120^{\circ} \mathrm{C}$, $80^{\circ} \mathrm{C}$ higher than the dew point of water, and Eq. (6) gave the average specific heat of the gases.

$$
\mathrm{c}_{\mathrm{p}, \text { average }}=\sum \mathrm{x}_{\mathrm{i}} \mathrm{c}_{\mathrm{p}, \mathrm{i}}
$$

For the analysis of the second configuration (Scenario 2), the data provided by the catalog of Wärtsilä (2019) were used, as shown in Tab. 4.

Table 4. Product Guide Wärtsilä 50DF (Wärtsilä, 2019).

\begin{tabular}{|c|c|c|c|}
\hline Load & $\begin{array}{c}\text { Heat rate } \\
(\mathbf{k J} / \mathbf{k W h})\end{array}$ & $\begin{array}{c}\text { Exhaust } \\
\text { mass flow } \\
(\mathbf{k g} / \mathbf{s})\end{array}$ & $\begin{array}{c}\text { Exhaust gas } \\
\text { temperature } \\
\left({ }^{\mathbf{}} \mathbf{C}\right)\end{array}$ \\
\hline $100 \%$ & 7,360 & 23.8 & 401 \\
\hline $75 \%$ & 7,720 & 18.4 & 445 \\
\hline $50 \%$ & 8,560 & 13.9 & 442 \\
\hline
\end{tabular}

A similar procedure for the gas turbine was made to the engine from the results shown in Tab. 4. In this case, the heat rate in $(\mathrm{kJ} / \mathrm{kWh})$ has already been supplied directly, so Eq. (7) obtains the efficiency values of an engine.

$$
\eta_{\text {engine }}=-0.0018 \mathrm{Lo}^{2}+0.4065 \mathrm{Lo}+26.171
$$

The engine's power was also parameterized, according to Eq. (8).

$$
W_{\text {engine }}=-0.0036 \mathrm{Lo}^{2}+152.71 \mathrm{Lo}+28.571
$$

Using the same logic as the first configuration, the thermal energy available in the exhaust gases of an engine was calculated using Eq. (1) using the values obtained by Eq. (9) and Eq. (10).

$$
\begin{aligned}
& \dot{\mathrm{m}}_{\text {exhaust,engine }}=0.0007 \mathrm{Lo}^{2}+0.09 \mathrm{Lo}+7.6 \\
& \mathrm{~T}_{\text {exhaust,engine }}=-0.00376 \mathrm{Lo}^{2}+4.82 \mathrm{Lo}+295
\end{aligned}
$$

These equations were used to calculate the thermal energy available in the exhaust gases of an engine, according to Eq. (1), where the temperature considered at the heat exchanger exit was also $120^{\circ} \mathrm{C}$, and Eq. (6) gave the average specific heat of the gases.

The calculation of pollutant gas emissions was performed by evaluating the mass flow of $\mathrm{CO}_{2}$ present in the exhaust gases of the equipment. The first step of this calculation was to perform the stoichiometric balance, Eq. (11) to evaluate each substance's molar fraction in the exhaust gases. Only gaseous fuel was used for the turbines, while for the engines $5 \%$ of diesel was admitted. Finally, the mass flow of $\mathrm{CO}_{2}$ divided by the electric demand was estimated from Eq. (12) to Eq. (14).

$$
\begin{aligned}
& 0.95\left(\mathrm{oN}_{2}+n \mathrm{CO}_{2}+m \mathrm{CH}_{4}+\mathrm{lC}_{2} \mathrm{H}_{6}+k \mathrm{C}_{3} \mathrm{H}_{8}\right. \\
& +\mathrm{j} \mathrm{C}_{4} \mathrm{H}_{10}, \text { iso }+i \mathrm{C}_{4} \mathrm{H}_{10}, n+h \mathrm{C}_{5} \mathrm{H}_{12}, \\
& \text { iso } \left.+g \mathrm{C}_{5} \mathrm{H}_{12}, n+f \mathrm{C}_{6+}\right)+0.05\left(\mathrm{C}_{14,5} \mathrm{H}_{25}\right) \\
& +a\left(\mathrm{O}_{2}+3.76 \mathrm{~N}_{2}\right)=b \mathrm{CO}_{2}+c \mathrm{H}_{2} \mathrm{O}+d \mathrm{~N}_{2}
\end{aligned}
$$

$$
\begin{aligned}
& \mathrm{y}_{\mathrm{CO}_{2}}=\frac{b}{b+c+d} \\
& x_{\mathrm{CO}_{2}}=\frac{y_{\mathrm{CO}_{2}} M_{\mathrm{CO}_{2}}}{\sum y_{i} M_{i}} \\
& \frac{\mathrm{m}_{\mathrm{CO}_{2}}}{W_{\text {elet }}}=\frac{\mathrm{m}_{\text {gas }} * \mathrm{x}_{\mathrm{CO}_{2}}}{W_{\text {elet }}}
\end{aligned}
$$




\section{RESULTS AND DISCUSSION}

Table 5 and Tab. 6 show the overall efficiency and emissions of the configuration with three turbines and five engines, respectively, for the five points of demand of the platform, as well as the load of the equipment to attend the demands. In the first scenario, the load distribution was equally made among the three turbines. In the second scenario, some of the engines worked at full load, while the other engines adjusted to the remaining electrical demand.

Table 5. Operating conditions of Scenario 1 for different loads of the platform

\begin{tabular}{|c|c|c|c|c|c|}
\hline $\begin{array}{c}\text { Demand } \\
\text { Points }\end{array}$ & $\boldsymbol{\eta}$ & $\begin{array}{c}\text { Turbine } \\
\mathbf{1}\end{array}$ & $\begin{array}{c}\text { Turbine } \\
\mathbf{2}\end{array}$ & $\begin{array}{c}\text { Turbine } \\
\mathbf{3}\end{array}$ & $\begin{array}{c}\mathbf{C O}_{2} \\
\text { emissions } \\
(\mathbf{g} / \mathbf{k W h})\end{array}$ \\
\hline Max O\&G & $35.4 \%$ & $83.0 \%$ & $83.0 \%$ & $83.0 \%$ & 619.16 \\
\hline Intermediate & $35.5 \%$ & $84.6 \%$ & $84.6 \%$ & $84.6 \%$ & 611.34 \\
\hline Valley & $35.3 \%$ & $82.0 \%$ & $82.0 \%$ & $82.0 \%$ & 624.09 \\
\hline $50 \% \mathrm{BSW}$ & $35.4 \%$ & $83.7 \%$ & $83.7 \%$ & - & 615.36 \\
\hline $\begin{array}{c}\mathrm{Max} \\
\mathrm{H}_{2} \mathrm{O} / \mathrm{CO}_{2}\end{array}$ & $35.1 \%$ & $79.5 \%$ & $79.5 \%$ & - & 636.79 \\
\hline
\end{tabular}

Table 6. Operating conditions of Scenario 2 for different loads of the platform

\begin{tabular}{|c|c|c|c|c|c|c|c|}
\hline $\begin{array}{c}\text { Demand } \\
\text { Points }\end{array}$ & $\boldsymbol{\eta}$ & $\begin{array}{c}\text { Eng. } \\
\mathbf{1}\end{array}$ & $\begin{array}{c}\text { Eng. } \\
\mathbf{2}\end{array}$ & $\begin{array}{c}\text { Eng. } \\
\mathbf{3}\end{array}$ & $\begin{array}{c}\text { Eng. } \\
\mathbf{4}\end{array}$ & $\begin{array}{c}\text { Eng. } \\
\mathbf{5}\end{array}$ & $\begin{array}{c}\mathbf{C O} 2 \\
\text { emissions } \\
\mathbf{( g / k W h )}\end{array}$ \\
\hline Max O\&G & $46.9 \%$ & $100 \%$ & $100 \%$ & $100 \%$ & $59.7 \%$ & $59.7 \%$ & 348.74 \\
\hline Interm. & $47.2 \%$ & $100 \%$ & $100 \%$ & $100 \%$ & $63.8 \%$ & $63.8 \%$ & 346.84 \\
\hline Valley & $46.7 \%$ & $100 \%$ & $100 \%$ & $100 \%$ & $57.1 \%$ & $57.1 \%$ & 349.93 \\
\hline $50 \% \mathrm{BSW}$ & $48.4 \%$ & $100 \%$ & $100 \%$ & $82,2 \%$ & - & - & 418.43 \\
\hline $\begin{array}{c}\mathrm{Max} \\
\mathrm{H}_{2} \mathrm{O} / \mathrm{CO}_{2}\end{array}$ & $47.7 \%$ & $100 \%$ & $100 \%$ & $67,8 \%$ & - & - & 425.87 \\
\hline
\end{tabular}

It was observed an efficiency difference of $11 \%$ comparing the Scenarios 1 and 2 . The equal distribution in Scenario 1 was made aiming at better results of overall efficiency in order to minimize the turbines losses due to their worse performance at partial load. On the other hand, due to the engine's better performance at partial load, it was possible to use some engines at full load while the other engines adjusted to the remaining electrical demand. Regarding emissions, Scenario 2 is showed a reduction between 30 and $40 \%$ when compared with Scenario 1 due to the higher efficiency of the internal combustion engines in comparison with the gas turbines. However, the system with engines presented other problems, such as non-fulfillment of thermal demand, which would be compensated with the use of auxiliary equipment, as present in Viana (2017), which would increase the emissions of the platform.

Table 7 presents the same information for the combined configuration proposed (Scenario 3), consisting of two turbines and two engines. In this scenario, the turbines worked at full load, looking to maximize their efficiency while the engines adjusted for the remaining electrical demand due to their better performance at partial load.

Table 7. Operating conditions of Scenario 3 for different loads of the platform.

\begin{tabular}{|c|c|c|c|c|c|c|}
\hline $\begin{array}{c}\text { Demand } \\
\text { Points }\end{array}$ & $\boldsymbol{\eta}$ & $\begin{array}{c}\text { Turb. } \\
\mathbf{1}\end{array}$ & $\begin{array}{c}\text { Turb. } \\
\mathbf{2}\end{array}$ & $\begin{array}{c}\text { Eng. } \\
\mathbf{1}\end{array}$ & $\begin{array}{c}\text { Eng. } \\
\mathbf{2}\end{array}$ & $\begin{array}{c}\mathbf{C O}_{2} \\
\text { emissions } \\
(\mathbf{g} / \mathbf{k W h})\end{array}$ \\
\hline $\begin{array}{c}\mathrm{Max} \\
\mathrm{O} \& \mathrm{G}\end{array}$ & $40.1 \%$ & $100 \%$ & $100 \%$ & $82.4 \%$ & - & 510.75 \\
\hline Interm. & $40.3 \%$ & $100 \%$ & $100 \%$ & $90.7 \%$ & - & 506.74 \\
\hline Valley & $39.9 \%$ & $100 \%$ & $100 \%$ & $77.3 \%$ & - & 513.44 \\
\hline $\begin{array}{c}50 \% \\
\mathrm{BSW}\end{array}$ & $41.1 \%$ & $100 \%$ & - & $56.8 \%$ & $56.8 \%$ & 481.82 \\
\hline $\begin{array}{c}\mathrm{Max} \\
\mathrm{H}_{2} \mathrm{O} / \mathrm{CO}_{2}\end{array}$ & $42.6 \%$ & $100 \%$ & - & $99.3 \%$ & - & 472.74 \\
\hline
\end{tabular}

Scenario 3 presented intermediate values of efficiency and emissions, besides some advantages concerning isolated systems, such as: load modulation performed through engines, keeping the turbines at full load, total attendance of electrical and thermal demands, without the need for auxiliary equipment, as shown in Tab. 8.

Table 8 . Meeting thermal demand by the different cogeneration configurations

\begin{tabular}{|c|c|c|c|}
\hline Demand Points & $\begin{array}{c}\text { Scenario } \\
\mathbf{1}\end{array}$ & $\begin{array}{c}\text { Scenario } \\
\mathbf{2}\end{array}$ & $\begin{array}{c}\text { Scenario } \\
\mathbf{3}\end{array}$ \\
\hline Max O\&G & $209 \%$ & $76 \%$ & $178 \%$ \\
\hline Intermediate & $218 \%$ & $80 \%$ & $184 \%$ \\
\hline Valley & $224 \%$ & $82 \%$ & $191 \%$ \\
\hline $50 \% \mathrm{BSW}$ & $134 \%$ & $47 \%$ & $103 \%$ \\
\hline $\mathrm{Max} \mathrm{H}_{2} \mathrm{O} / \mathrm{CO}_{2}$ & $150 \%$ & $53 \%$ & $110 \%$ \\
\hline
\end{tabular}

*Values considering attendance $(100 \%)$ of the electrical demand in all demand points and scenarios fully.

It was noted that Scenario 1 presents surplus thermal availability that allows the application of recovery systems. The same occurs in the first 3 points of demand in Scenario 3 since the last 2 points do not present such significant surplus values. Whereas the cogeneration system does not attend the thermal demand, like Scenario 2, some alternatives were presented in Viana's work (2017), where it is possible to use auxiliary burners in a post-burning system using the gas produced on the platform or electric heaters. Table 9 presents the comparison between the $\mathrm{CO}_{2}$ emissions in the three scenarios evaluated in this work. In Scenario 2, the values also consider the emissions produced by an auxiliary burner required to attend to the remaining thermal demand in the platform. An additional burner's gas consumption was estimated, dividing the remaining thermal demand by the fuel LHV. To calculate the $\mathrm{CO} 2$ percentage in the exhaust gas flow was used, the same procedure was made using Eq. (11) to Eq (14). 
Table 9. CO2 emissions in the three different cogeneration configurations

\begin{tabular}{|c|c|c|c|}
\hline \multirow{2}{*}{$\begin{array}{c}\text { Demand } \\
\text { Points }\end{array}$} & Scenario 1 & Scenario 2* & Scenario 3 \\
\cline { 2 - 4 } & $\begin{array}{c}\mathrm{CO}_{2} \text { emissions } \\
(\mathrm{g} / \mathrm{kWh})\end{array}$ & $\begin{array}{c}\mathrm{CO}_{2} \text { emissions } \\
(\mathrm{g} / \mathrm{kWh})\end{array}$ & $\begin{array}{c}\mathrm{CO}_{2} \text { emissions } \\
(\mathrm{g} / \mathrm{kWh})\end{array}$ \\
\hline Max O\&G & 619.16 & 384.16 & 510.75 \\
\hline Intermediate & 611.34 & 375.55 & 506.74 \\
\hline Valley & 624.09 & 375.62 & 513.44 \\
\hline $50 \% \mathrm{BSW}$ & 615.36 & 540.14 & 481.82 \\
\hline $\begin{array}{c}\mathrm{Max} \\
\mathrm{H}_{2} \mathrm{O} / \mathrm{CO}_{2}\end{array}$ & 636.79 & 524.33 & 472.74 \\
\hline \multicolumn{2}{|c|}{} & \multicolumn{2}{|c}{} \\
\hline \multicolumn{2}{|c|}{}
\end{tabular}

It was noticed that the use of burners increased emissions mainly in the last two points, where it was observed the lowest attendance of thermal demand by the engines. It was also possible to observe that Scenario 3 presented the lowest emission values at the end of the platform life, fully meeting electrical and thermal demands.

Also, one of the most critical parameters of a platform is the occupation of it is space. Because of this, Tab. 10 brings the physical occupation of the different configurations proposed in terms of occupied area and weight.

Table 10. Physical occupation of the different configurations.

\begin{tabular}{|c|c|c|c|}
\hline Dimensions & Scenario 1 & Scenario 2 & Scenario 3 \\
\hline Area $\left[\mathrm{m}^{2}\right]$ & 148.72 & 410.88 & 248.50 \\
\hline Weight [ton] & 106.8 & $1,361.4$ & 653.6 \\
\hline
\end{tabular}

Scenario 2 occupies a $176 \%$ larger area and increases weight by $1175 \%$ compared to Scenario 1 , while Scenario 3 occupies a space only $67 \%$ larger and increases weight by $400 \%$ compared to Scenario 1. It is necessary to highlight that these values do not consider the area and weight-related by auxiliary equipment such as burners or electric heaters essential for Scenario 2 to fully attend to the thermal demand.

\section{CONCLUSIONS}

In this work, a combined configuration proposal was presented with engines and turbines to attend to the electrical and thermal demand of an FPSO. It was noticed that the combined configuration showed intermediate values of efficiency, $\mathrm{CO} 2$ emissions, and physical occupation when using both pieces of equipment. The highest overall efficiency value in the configuration using only turbines occurred at the "Intermediate" point reaching 35.5\%, due to the characteristics of the demand of the platform, which needs $65 \mathrm{MW}$, causing the turbines to work at partial loads, but close to the nominal. Scenario 2, the highest overall efficiency value was seen at the "50\% BSW" point reaching $48.4 \%$. The demands were about $43 \mathrm{MW}$, causing two engines to be turned off and with the other three connected, two work at full load and one-act with a partial load close to the nominal. Finally, the highest overall efficiency value in Scenario 3 was seen at the "Max $\mathrm{H} 2 \mathrm{O} / \mathrm{CO} 2$ " point reaching $42.6 \%$, with the demand of about 41 MW, causing a turbine and an engine to be shut down. The engine that remained worked practically at full load with the other turbine kept at full load in all scenarios.

The configuration using only turbines presented a lower $\mathrm{CO} 2$ emission value at the point of demand where it reached the highest overall efficiency value, emitting $611.34 \mathrm{~g} / \mathrm{kWh}$ of CO2. On the other hand, the configuration using only engines presented a lower $\mathrm{CO} 2$ emission value at the "Intermediate" point, emitting $373.45 \mathrm{~g} / \mathrm{kWh}$ of $\mathrm{CO} 2$ considering the emissions produced by the auxiliary burner to attend to the thermal demand of the platform entirely. The combined configuration and the configuration using only turbines, presented lower $\mathrm{CO} 2$ emission values at the point of demand where it reached the highest overall efficiency value, emitting $472.74 \mathrm{~g} / \mathrm{kWh}$ of CO2. This result represents a decrease of approximately $22.6 \%$ in $\mathrm{CO} 2$ emissions comparing with the demand point with the lowest $\mathrm{CO} 2$ emission in the current scenario (Scenario 1) on the platforms. The combined configuration also presented the lowest emission values at the end of the platform life ("50\% BSW" and "Max H2O/CO2"), showing a decrease of approximately $10 \%$ in $\mathrm{CO} 2$ emissions compared with the same demand points of the configuration using engines and an auxiliary burner (Scenario 2).

In the matter of physical occupation of the platform, the required occupied area and the weightrelated to the equipment increases in the two configurations that present an increase in overall efficiency and reduction in $\mathrm{CO} 2$ emissions, however, the combined configuration is approximately $40 \%$ smaller and is $52 \%$ lighter than the configuration using only engines. Also, it is worth mentioning that combined configuration meets the thermal demand without increasing the platform's complexity with auxiliary equipment.

Therefore, it was possible to observe that the combined configuration presented several advantages about isolated systems, proving to be an excellent option for sustainable energy generation, reducing emissions of polluting gases and greater flexibility of its operation in relation to configuration only with turbines, and physical occupation regarding configuration only with engines.

\section{REFERENCES}

Acevedo, V.L., 2016. Diagnóstico de Emissões de Gases de Efeito Estufa em Plataformas FPSO. M.Sc. thesis, Universidade Estadual de Campinas, Campinas, Brasil. 
Dias, R., 2017. Análise Exergoeconômica da Cogeração em Instalações Marítimas Petrolíferas. M.Sc. thesis, Universidade Estadual de Campinas, Campinas, Brasil.

Gallo, W.L.R., Gallego, A.G., Acevedo, V.L., Dias, R, Ortiz, H.Y., Valente, B.A., 2017. "Exergy analysis of the compression systems and its prime movers for a FPSO unit." Journal of Natural Gas Science \& Engineering, Vol. 44, pp. 287-298.

Gas Turbine World, 1994. Gas Turbine World Handbook 1993-1994. Pequot Publishing, Fairfield.

Leffler, W. L., Pattarozzi, R., Sterling, G., 2003. Deepwater Petroleum Exploration \& Production: A Nontechnical Guide.

Neto, J. B. O., and Shima, W. T., 2008. "Technological trajectories in the offshore segment: environment and opportunities." Journal of Contemporary Economics, Vol. 12, No. 2, pp. 301332.

Silva, T. C., 2016. Dimensionamento de Trocadores de Calor para Recuperação de Calor Residual em Sistema ORC de uma FPSO. M.Sc. thesis, Universidade Federal de Itajubá, Itajubá, Brasil.

Viana, A. M. M., 2017. Cogeração em Plataformas de Produção de Petróleo e Gás Natural utilizando Motores de Combustão Interna Bicombustíveis Diesel/Gás. M.Sc. thesis, Universidade Estadual de Campinas, Campinas, Brasil.

Wärtsilä, 2019. Wärtsilä 50DF Product Guide, Vaasa.

Wärtsilä, 2020. "Gas and multi-fuel power plants." $27 \quad$ May 2020 $<$ https://cdn.wartsila.com/docs/default-source/powerplants-documents/downloads/brochures/gas-andmulti-fuel-power-plants-2017.pdf $>$. 